\title{
PERSEPSI ANAK JALANAN TERHADAP BIMBINGAN SOSIAL MELALUI RUMAH SINGGAH DI KOTAMADYA BANDUNG ${ }^{1}$
}

\section{(PERCEPTION OF STREET CHILDREN TOWARD SOCIAL GUIDANCE IN OPEN HOUSE PROGRAM AT BANDUNG CITY)}

\author{
Sr Tjahjorini, Margono Slamet, Pang S. Asngari, \\ dan Djoko Susanto
}

\begin{abstract}
The street children has become an important phenomenon in urban areas. Most of the children spent their time on the street or in other public areas. Government throught Social Welfare Departement developed an transit house program which providing social guidance fo ther street children, but the budget can not cover all of the children. Many of the children are still on the street that cause them to be out of control and easily trapped in juvenile delinquency. The study tried to understand perception of the children on the social guidance of the transit house program, since there are not enough information about the issue. The study used quantitative and qualitative data and analized in non parametric statistic. Bandung was selected as location of the study since the city is one of cities in Indonesia that has street children problems. Population of the study are street children of 6-18 years old. Stratifield random sampling technique was used to get 60 respondents. The data was collected through interview schedule, field observation and desk study. The research fond that the perception of the respondents toward social guidance program is negative in terms of physical, mentality, social and skill. But, the respondent that involved in the program less or equal to 6 months is better than whose that involved 7-12 months and more than 13 months, especially in terms of mental and skill guidance. Based on the finding, a reorientation of the program is needed throught in form of guidance and councelling package that short in time (less than 6 months), relevance with interest and talent of the children, emphasize on developing the children skill, but still concern with physical, mental and social development.
\end{abstract}

Keywords: Perception, Street Children, Social Guidance, Open House Program

\section{Pendahuluan}

Krisis ekonomi yang terjadi di awal tahun 1997 yang diperberat oleh bencana alam kekeringan, telah menyebabkan banyak orang tua dan keluarga yang mengalami keterpurukan ekonomi, sehingga tidak lagi dapat memenuhi hak dan kebutuhan anak untuk tumbuh dan berkembang. Akibat lebih lanjut dari kondisi tersebut adalah semakin banyaknya anak yang harus meninggalkan sekolah guna mengais nafkah di jalanan. 
Situasi jalanan selain memberikan peluang bagi anak untuk melakukan berbagai kegiatan yang dapat menghasilkan nafkah atau sekedar untuk bergaul, juga sangat membahayakan bagi kehidupan anak-anak. Hal ini disebabkan anak secara psikologis mudah dipengaruhi dan memiliki perilaku imitatif yang kuat.

Sejauh ini belum ada kepastian jumlah seluruh anak jalanan di Indonesia. Perkiraan yang didasarkan pada data gelandangan dan pengemis, sedikitnya terdapat 50 ribu orang anak jalanan (Irwanto, 1998). Sedang jumlah anak jalanan yang ada di Kotamadya Bandung mencapai 11.000 orang. Namun tidak semua dari jumlah tersebut menerima bimbingan sosial, sehingga masih banyak anak jalanan yang sifatnya liar karena tidak ditangani oleh rumah singgah atau lembaga-lembaga yang menangani anak jalanan, sehingga mereka cenderung rawan terhadap tindakan yang menentang norma dan nilai yang berlaku di masyarakat.

Menyadari hal ini, maka diperlukan upaya penanganan permasalahan anak jalanan yang salah satunya dilakukan melalui rumah singgah yang merupakan Lembaga Swadaya Masyarakat. Dengan pembina rumah singgah yang bertindak sebagai agen perubahan atau change of agent yang juga bertindak sebagai penyuluh, yang berupaya menolong agar orang tersebut dapat menolong dirinya sendiri atau help people to help themselves.

Namun demikian ada keterbatasan kemampuan yang dimiliki oleh Lembaga Swadaya Masyarakat dalam menangani anak jalanan. Hal ini seperti dikemukakan oleh Irwanto (1998) bahwa :

$\begin{array}{lrr}\text { "Lembaga } & \text { Swadaya } \\ \text { Masyarakat tidak } & \text { memiliki } \\ \text { kapasitas } & \text { menangani proyek } \\ \text { berskala besar } & \begin{array}{r}\text { karena } \\ \text { kemauan }\end{array}\end{array}$

membantunya sangat besar, namun jumlah stafnya minim dan mereka juga seringkali tak memiliki ketrampilan dan pengetahuan yang cukup untuk menangani masalah anak jalanan. Karenanya jika tidak ada kerjasama antara Lembaga Swadaya Masyarakat dan pemerintah maka akan mengakibatkan karya lembaga swadaya masyarakat seringkali terlalu kecil untuk terasa manfaatnya bagi masyarakat luas".

Keterbatasaan kemampuan tersebut, sedikit banyak akan berpengaruh pada pelayanan yang diberikan. Padahal bila mengingat rumah singgah memiliki pembina yang dipandang sebagai agen perubahan sekaligus sebagai penyuluh, diharapkan kondisi tersebut tidak terjadi.

Berdasarkan latar belakang tersebut maka dirumuskan permasalahan penelitian, yaitu :

(1) Apakah ada perbedaan faktor-faktor yang berkaitan dengan anak jalanan antara yang dibina di rumah singgah yang dapat dana dengan yang tidak dapat dana ?

(2) Apakah ada perbedaan persepsi anak jalanan terhadap pembinaan yang dilakukan oleh rumah singgah yang dapat dana bantuan dengan yang tidak dapat dana ?

(3) Faktor-faktor internal dan eksternal apa yang berhubungan dengan persepsi anak jalanan terhadap pembinaan di rumah singgah?

(4) Bentuk pembinaan apa yang paling dipahami dan dianggap paling penting oleh anak jalanan dalam pembinaannya di rumah singgah? 
Berdasarkan rumusan permasalahan maka disusun hipotesis penelitian sebagai berikut :

(1) Tidak ada perbedaan faktor yang berkaitan dengan anak jalanan secara nyata antara yang dibina di rumah singgah yang dapat dana dengan yang tidak dapat dana.
(2) Tidak ada perbedaan persepsi anak jalanan terhadap pembinaan secara nyata antara rumah singgah yang dapat dana dengan yang tidak dapat dana.

(3) Terdapat hubungan antara faktor-faktor yang berkaitan dengan anak jalanan secara nyata dengan pembinaan di rumah singgah yang dapat dana dengan yang tidak dapat dana.

\section{Kerangka Berpikir}

\begin{tabular}{|ll|}
\hline \multicolumn{2}{|c|}{ Ciri Anak Jalanan } \\
\hline - & Umur anak jalanan \\
- & Tingkat pendidikan formal \\
- & Pengalaman menjadi anak jalanan \\
- & Jenis anak jalanan \\
- & Tingkat keaktifan anak jalanan \\
\hline
\end{tabular}

\section{Tingkat Pemenuhan Kebutuhan} Anak Jalanan

- Kebutuhan fisiologis

- Kebutuhan akan rasa aman

- Kebutuhan akan rasa memiliki

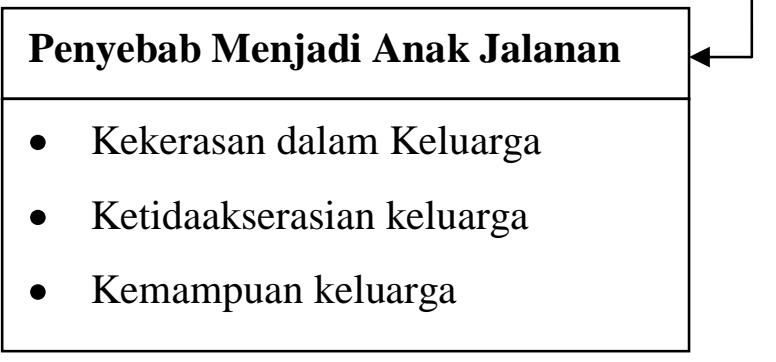

\section{Persepsi Anak Jalanan} terhadap Bimbingan Sosial

- Pembinaan Fisik

- Pembinaan Mental

- Pembinaan Sosial

- Pembinaan Ketrampilan

\section{$\uparrow$}

Tipe Kepribadian Pembina Rumah Singgah

- Penuh Perhatian

- Penuh Motivasi

- Mememberi contoh

- Dinamis

- Tangguh

- Berani berkorban

- Hubungan informal

- Mampu berkomunikasi 
(4) Terdapat bentuk pembinaan yang dirasakaan oleh anak jalanan paling dipahami dan paling penting dalam rumah singgah.

\section{Metode Penelitian}

Penelitian menggunakan jenis penelitian deskriptif, yang bertujuan membuat gambaran mengenai situasi atau kejadian serta dilakukan pengujian hipotesa. Populasi penelitian ini adalah 200 orang anak jalanan yang dibina langsung oleh 4

\section{Hasil Penelitian}

Perbandingan faktor-faktor yang berkaitan dengan anak jalanan antara yang dibina oleh rumah singgah yang dapat dana dengan yang tidak dapat dana terlihat pada Tabel 2.

Mengenai ciri anak jalanan diwakili oleh variabel $\mathrm{X} 1$ sampai $\mathrm{X} 7$ yang memperlihatkan basil tidak ada perbedaan yang nyata antara kedua rumah singgah. Dengan basil tabulasi dominan : untuk $\mathrm{X}_{1}$

Tabel 1. Jumlah Responden Berdasarkan Lamanya Anak Tinggal di Rumah Singgah

\begin{tabular}{|c|c|c|c|}
\hline Rumah Singgah & $\begin{array}{c}\text { Tinggal }<6 \\
\text { bulan }\end{array}$ & $\begin{array}{c}\text { Tinggal antara } \\
6-12 \text { bulan }\end{array}$ & Tinggal $>13$ bulan \\
\hline Rumah Singgah I & 5 orang & 5 orang & 5 orang \\
\hline Rumah Singgah II & 5 orang & 5 orang & 5 orang \\
\hline Rumah Singgah III & 5 orang & 5 orang & 5 orang \\
\hline Rumah Singgah IV & 5 orang & 5 orang & 5 orang \\
\hline Jumlah & 20 orang & 20 orang & 20 orang \\
\hline
\end{tabular}

rumah singgah yang terpilih. Penarikan sample dilakukan dengan cara stratified random sampling, dengan pengelompokan responden untuk masing-masing rumah singgah berdasarkan strata lmanya anak tinggal di rumah singgah terlihat pada Table 1. Jumlah sampel anak jalanan adalah sebanyak 60 orang.

Alat analisis yang digunakan adalah statistik non parametrik, yaitu Uji Mann Whitney untuk menguji hipotesa pertama dan kedua, uji korelasi Rank Spearman untuk menguji hipotesa ketiga, dan uji statistik Chi-Square untuk menguji hipotesis keempat. sebanyak $98.33 \%$ berusia antara 11-18 tahun ; untuk $\mathrm{X}_{2}$ sebanyak $76.67 \%$ memiliki tingkat pendidikan formal ratarata Sekolah Dasar ; untuk $X_{3}$ sebanyak 75\% didominasi oleh pengalaman menjadi anak jalanan lebih dari 2 tahun; untuk $\mathrm{X}_{4}$, sebanyak $50 \%$ dengan jenis rentan menjadi anak jalanan atau vulnerable to be street children, sedang dengan jenis hidup di jalanan atau children of the street $13.33 \%$; untuk $\mathrm{X}_{5}$, sebanyak $35 \%$ dengan tingkat keaktifan yang tinggi ; untuk $\mathrm{X}_{6}$, sebanyak $53.33 \%$ dengan tingkat kreatifitas yang tinggi ; untuk $\mathrm{X}_{7}$, sebanyak $63.33 \%$ dengan tingkat kemandirian yang tinggi.

Kondisi tersebut memperlihatkan bahwa selain memiliki kekurangan, masing-masing anak jalananpun memiliki kelebihan sebagai anak yang tentunya 
berbeda dengan orang dewasa. Sesuai dengan pendapat Goode (1993) bahwa anak-anak bukanlah manusia dalam bentuk mini. Anak adalah anak ; mereka mempunyai pikiran, perasaan, sikap dan minat yang berbeda dengan orang dewasa. Anak harus dianggap dan diperlakukan sebagai anak. Selain itu setiap anak adalah unik yang berbeda satu dengan yang lain.

Mengenai tingkat pemenuhan kebutuhan anak jalanan diwakili oleh variabel $\mathrm{X}_{8} \quad$ sampai $\mathrm{X}_{10}$ yang memperlihatkan hasil tidak ada perbedaan antara kedua rumah singgah. Dengan hasil tabulasi dominan : untuk $\mathrm{X}_{8}$, sebanyak $46.67 \%$ menyatakan kebutuhan fisik terpenuhi dengan baik dan $26.67 \%$ terpenuhi dengan tidak baik ; untuk $\mathrm{X}_{8}$, sebanyak $40 \%$ menyatakan terpenuhi dengan kurang baik dan $31,67 \%$ terpenuhi dengan tidak baik ; untuk $\mathrm{X}_{10}$, sebanyak $61.67 \%$ menyatakan terpenuhi dengan baik dan $15 \%$ terpenuhi dengan tidak baik.

Kondisi di atas memperlihatkan bahwa keberadaan anak di jalanan dan memperoleh pembinaan dari rumah singgah, justru dapat memenuhi sebagian dari kebutuhan anak. Hal ini sesuai dengan pendapat Maslow (1984) bahwa seseorang yang dirintangi dalam memenuhi kebutuhan pokoknya yang manapun hampirhampir digambarkan sebagai orang

Tabel 2. Distribusi Faktor-faktor yang Berkaitan dengan Anak jalanan Antara Rumah Singgah Dapat Dana dan Tidak Dapat Dana.

\begin{tabular}{|l|c|c|c|}
\hline \multirow{2}{*}{ Faktor-faktor } & \multicolumn{2}{c|}{ Rataan } & \multirow{2}{*}{ Nilai-p @ } \\
\cline { 2 - 3 } & Dapat dana & Tidak dapat dana & \\
\hline Umur anak j alanan (X 1) & 31.03 & 29.97 & 0.795 \\
\hline Tingkat pendidikan formal (X2) & 30.50 & 30.50 & 1.000 \\
\hline $\begin{array}{l}\text { Pengalaman menjadi anak } \\
\text { jalanan (X3) }\end{array}$ & 29.88 & 31.12 & 0.716 \\
\hline Jenis anak jalanan (X4) & 31.47 & 29.53 & 0.660 \\
\hline $\begin{array}{l}\text { Tingkat keaktifan anak jalanan } \\
\text { (X5) }\end{array}$ & 28.85 & 32.15 & 0.438 \\
\hline $\begin{array}{l}\text { Tingkat kreatifitas anak jalanan } \\
\text { (X6) }\end{array}$ & 31.62 & 29.38 & 0.6607 \\
\hline $\begin{array}{l}\text { Tingkat kemandirian anak } \\
\text { jalanan (X7) }\end{array}$ & 29.10 & 31.90 & 0.514 \\
\hline Kebutuhan fisiologis (X8) & 31.77 & 29.23 & 0.567 \\
\hline Kebutuhan akan rasa aman (X9) & 33.85 & 27.77 & 0.120 \\
\hline $\begin{array}{l}\text { Kebutuhan akan rasa memiliki } \\
\text { (X 10) }\end{array}$ & 33.23 & 31.30 & 0.213 \\
\hline Kekerasan dalam keluarga (X 11) & 29.70 & 29.98 & 0.701 \\
\hline Ketidakserasian keluarga (X12) & 31.02 & 31.00 & 0.814 \\
\hline Kemampuan keluarga (X13) & 30.00 & & 0.317 \\
\hline Penuh perhatian (X14) & 33.35 & 27.65 & 0.197 \\
\hline Penuh motivasi (X15) & 32.02 & 28.98 & 0.421 \\
\hline Memberi contoh (X 16) & 31.20 & 29.80 & 0.730 \\
\hline Dinamis (X17) & 31.90 & 29.10 & 0.484 \\
\hline Tangguh (X18) & 31.22 & 29.78 & 0.744 \\
\hline Berani berkorban (X 19) & 35.82 & 25.18 & 0.015 \\
\hline Hubungan informal (x200 & 31.88 & 29.12 & 0.529 \\
\hline Mampu berkomunikasi (X21) & 36.37 & 24.63 & 0.007 \\
\hline
\end{tabular}


yang sakit jiwa atau paling sedikit kurang manusiawi. Sebaliknya seseorang yang sehat terutama dimotivasikan oleh kebutuhannya untuk mengembangkan dan mewujudkan potensi dan kapasitasnya sepenuh-penuhnya.

Mengenai penyebab menjadi anak jalanan diwakili oleh variable $\mathrm{X}_{11}$ sampai $\mathrm{X}_{13}$ yang memperlihatkan hasil tidak ada perbedaan antara kedua rumah singgah. Dengan hasil tabulasi dominan : untuk $\mathrm{X}_{11}$, sebanyak $45 \%$ menyatakan tidak terjadi kekerasan dan $23.33 \%$ terjadi kekerasan dalam keluarga ; untuk $X_{12}$, sebanyak $45 \%$ menyatakan tidak terjadi ketidakserasian dan $33.33 \%$ terjadi ketidakserasian dalam keluarga ; untuk $\mathrm{X}_{13}$, sebanyak $93.33 \%$ menyatakan dari keluarga tidak mampu.

Kondisi di atas memperlihatkan bahwa faktor penyebab anak turun ke jalanan bisa lebih dari satu, dengan penyebab dominan adalah ketidakmampuan keluarga. Hal tersebut sesuai dengan yang dikemukakan UNICEF, anak jalanan adalah anak yang menghabiskan sebagian besar waktunya di jalan untuk bekerja atau beraktivitas lain. Mereka tinggal di jalanan karena tercampakan atau dicampakan dari keluarga-keluarga yang tidak mampu menanggung beban hidup, terdesak oleh kemiskinan dan kehancuran keluarga.

Umumnya mereka berasal dari keluarga tidak mampu atau korban dari keluarga bermasalah. Dengan kata lain, ketidakmampuan keluarga untuk menjalankan fungsinya dapat berpengaruh pada anak. Hal tersebut sesuai dengan pendapat Yatim (1986) bahwa tidak berfungsinya salah satu dari fungsi orang tua akan menyebabkan suatu ketegangan, perasaan tidak aman, dan frustrasi. Semuanya ini menyebabkan hambatan bagi perkembangan kepribadian anak. Biasanya mereka mencari sesuatu untuk dapat menghilangkan perasaan itu. Dalam hal ini termasuk anak turun ke jalanan.

Mengenai tipe kepribadian pembina rumah singgah diwakili oleh variabel $\mathrm{X}_{14}$ sampai $\mathrm{X}_{21}$ yang memperlihatkan hasil, 6 variabel tidak ada perbedaan dan 2 variabel ada perbedaan antara kedua rumah singgah. Dengan basil tabulasi dominan : untuk $\mathrm{X}_{14}$, sebanyak $63.33 \%$ menyatakan pembina tidak memperhatikan ; untuk $\mathrm{X}_{15}$, sebanyak $76.67 \%$ menyatakan pembina tidak memotivasi ; untuk $\mathrm{X}_{16}$, sebanyak $60 \%$ menyatakan pembina tidak memberi contoh ; untuk $\mathrm{X}_{17}$, sebanyak $73.33 \%$ menyatakan pembina tidak dinamis ; untuk $\mathrm{X}_{18}$, sebanyak $41.67 \%$ menyatakan pembina tidak tangguh ; untuk $\mathrm{X}_{19}$, sebanyak $36.67 \%$ menyatakan pembina di rumah singgah dapat dana dan sebanyak $60 \%$ di rumah singgah yang tidak dapat dana tidak berani berkorban (menunjukan adanya perbedaan) ; untuk $\mathrm{X}_{20}$, sebanyak $56.67 \%$ menyatakan pembina tidak melakukan hubungan informal ; untuk $\mathrm{X}_{21}$, sebanyak $50 \%$ menyatakan pembina di rumah singgah dapat dana dan $70 \%$ di rumah singgah tidak dapat dana tidak mampu berkomunikasi (menunjukan adanya perbedaan).

Dari kondisi di atas terlihat bahwa pembina di kedua rumah singgah kurang mampu menjalankan tugas dan peranannya dengan baik. Hal tersebut sesuai dengan pendapat Szilagyi (Gibson dan Donnely,

Tabel 3. Distribusi Persepsi Anak Jalanan Terhadap Pembinaan Dalam Rumah Singgah

\begin{tabular}{|l|c|c|c|}
\hline \multirow{2}{*}{ Pembinaan dalam Rumah Singgah } & \multicolumn{2}{|c|}{ Rataan } & \multirow{2}{*}{ Nilai-p (a) } \\
\cline { 2 - 4 } & Dapat dana & Tidak dapat dana & \\
\hline Pembinaan fisik (Y1) & 34.10 & 26.90 & 0.092 \\
\hline Pembinaan mental (Y2) & 30.02 & 30.98 & 0.817 \\
\hline Pembinaan sosial (Y3) & 29.52 & 31.48 & 0.607 \\
\hline Pembinaan ketrampilan (Y4) & 25.73 & 35.27 & 0.024 \\
\hline
\end{tabular}


1994) bahwa ketepatan dalam persepsi peran mempunyai pengaruh yang menentukan hasil karya, sehingga ketepatan pembina menjalankan tugas dan peranannya akan berpengaruh pada pelaksanaan pembinaan yang ada.

Persepsi anak jalanan terhadap pembinaan di rumah singgah antara yang dapat dana dengan yang tidak dapat dana terlihat pada Tabel 3 .
Mengenai persepsi anak jalanan terhadap bimbingan sosial dalam bentuk pembinaan diwakili oleh variabel Y1 sampai Y4, yang memperlihatkan hasil tiga variable tidak ada perbedaan dan satu variabel ada perbedaan di kedua rumah singgah. Dengan tabulasi hasil dominan : unrtuk Y1, sebanyak 63. 33\% memiliki persepsi yang tidak baik terhadap pembinaan fisik, untuk Y2, sebanyak $56.67 \%$ memiliki persepsi yang tidak baik terhadap pembinaan mental ; untuk Y3,

Tabel 4. Faktor-Faktor yang Berhubungan dengan Persepsi Anak Jalanan Terhadap Pembinaan di Rumah Singgah yang Dapat Dana

\begin{tabular}{|l|c|c|c|c|}
\hline \multirow{2}{*}{ Faktor-Faktor } & \multicolumn{4}{c|}{ Nilai-p } \\
\cline { 2 - 5 } & Fisik & Mental & Sosial & Ketrampilan \\
\hline Umur anak jalanan (X 1) & 0.079 & 0.267 & 0.289 & 0.131 \\
\hline $\begin{array}{l}\text { Tingkat pendidikan formal } \\
\text { (X2) }\end{array}$ & 0.047 & -0.024 & 0.134 & 0.137 \\
\hline $\begin{array}{l}\text { Pengalaman menjadi anak } \\
\text { jalanan (X3) }\end{array}$ & 0.317 & -0.202 & 0.317 & -0.162 \\
\hline Jenis anak jalanan (X4) & 0.122 & 0.041 & 0.127 & -0.209 \\
\hline $\begin{array}{l}\text { Tingkat keaktifan anak } \\
\text { ialanan (X5) }\end{array}$ & 0.150 & 0.033 & -0.144 & $0.373^{*}$ \\
\hline $\begin{array}{l}\text { Tingkat kreatifitas anak } \\
\text { jalanan (X6) }\end{array}$ & $0.386^{*}$ & $0.434^{*}$ & 0.224 & 0.241 \\
\hline $\begin{array}{l}\text { Tingkat kemandirian anak } \\
\text { jalanan (X7) }\end{array}$ & 0.057 & -0.024 & -0.260 & -0.108 \\
\hline Kebutuhan fisiologis (X8) & $0.392^{*}$ & 0.243 & 0.162 & 0.118 \\
\hline $\begin{array}{l}\text { Kebutuhan akan rasa aman } \\
\text { (X9) }\end{array}$ & 0.181 & 0.245 & 0.086 & $0.489^{* *}$ \\
\hline $\begin{array}{l}\text { Kebutuhan akan rasa } \\
\text { memiliki (X 10) }\end{array}$ & 0.066 & 0.092 & -0.176 & $0.528^{* *}$ \\
\hline Kekerasan keluarga (X11) & 0.127 & 0.041 & -0.056 & -0.075 \\
\hline $\begin{array}{l}\text { Ketidakserasian keluarga } \\
\text { X12) }\end{array}$ & 0.128 & -0.046 & 0.060 & $0.449^{*}$ \\
\hline Kemampuan keluarga (X13) & - & - & - & - \\
\hline Penuh perhatian (X14) & 0.222 & -0.349 & $0.395 *$ & -0.026 \\
\hline Penuh motivasi (X15) & $0.473^{* *}$ & 0.282 & -0.221 & 0.318 \\
\hline Memberi contoh (X 16) & 0.242 & 0.277 & 0.311 & 0.047 \\
\hline Dinamis (X17) & -0.080 & 0.171 & 0.093 & -0.126 \\
\hline Tangguh (X18) & 0.013 & 0.099 & 0.082 & 0.171 \\
\hline Berani berkorban (X 19) & 0.275 & 0.238 & 0.258 & 0.011 \\
\hline Hubungan informal (X20) & $0.377^{*}$ & 0.313 & $0.580^{* *}$ & 0.121 \\
\hline Mampu berkomunikasi (X21) & 0.266 & $0.414^{*}$ & 0.194 & 0.250 \\
\hline & & & & \\
\hline
\end{tabular}


sebanyak $73.33 \%$ memiliki persepsi yang tidak baik terhadap pembinaan sosial ; untuk $\mathrm{Y}_{4}$, sebanyak $66.6 \%$ di rumah singgah yang dapat dana dan $56.67 \%$ di rumah singgah yang tidak dapat dana memiliki persepsi yang tidak baik terhadap pembinaan ketrampilan (menunjukan adanya perbedaan).
Dari kondisi tersebut terlihat bahwa persepisi anak jalanan cenderung tidak baik terhadap semua bentuk pembinaan di kedua rumah singgah, sehingga hal ini berpengaruh pada ketidaksediaan anak untuk mengikuti pembinaan. Meski memiliki persepsi berbeda antar anak jalanan, namun memiliki kecenderungan yang sama. Hal ini terkait dengan situasi

Tabel 5. Faktor-Faktor yang Berhubungan dengan Persepsi Anak Jalanan Terhadap Pembinaan di Rumah Singgah yang Tidak Dapat Dana

\begin{tabular}{|c|c|c|c|c|}
\hline \multirow{2}{*}{ Faktor-Faktor } & \multicolumn{4}{|c|}{ Nilai-p } \\
\hline & Fisik & Mental & Sosial & Ketrampilan \\
\hline Umur anak jalanan (X1) & 0.267 & $-0.684 * *$ & $-0.541 * *$ & $-0.704 *$ \\
\hline $\begin{array}{l}\text { Tingkat pendidikan formal } \\
\text { (X2) }\end{array}$ & $0.567 * *$ & -0.237 & -0.301 & $-0.376^{*}$ \\
\hline $\begin{array}{l}\text { Pengalaman menjadi anak } \\
\text { jalanan (X3) }\end{array}$ & 0.134 & -0.308 & 0.088 & 0.208 \\
\hline Jenis anak jalanan (X4) & -0.321 & -0.003 & -0.028 & 0.257 \\
\hline $\begin{array}{l}\text { Tingkat keaktifan anak } \\
\text { jalanan (X5) }\end{array}$ & -0.210 & 0.257 & 0.329 & 0.309 \\
\hline $\begin{array}{l}\text { Tingkat kreatifitas anak } \\
\text { jalanan (X6) }\end{array}$ & -0.054 & 0.001 & 0.049 & -0.110 \\
\hline $\begin{array}{l}\text { Tingkat kemandirian anak } \\
\text { jalanan (X7) }\end{array}$ & -.359 & 0.033 & 0.014 & -0.174 \\
\hline Kebutuhan fisiologis (X8) & 0.136 & -0.050 & -0.279 & -0.018 \\
\hline $\begin{array}{l}\text { Kebutuhan akan rasa aman } \\
\text { (X9) }\end{array}$ & -0.052 & $0.461 *$ & 0.322 & 0.349 \\
\hline $\begin{array}{l}\text { Kebutuhan akan rasa } \\
\text { memiliki (X 10) }\end{array}$ & -0.165 & $0.630^{* *}$ & 0.230 & 0.346 \\
\hline $\begin{array}{l}\text { Kekerasan dalam keluarga } \\
\text { (X11) }\end{array}$ & 0.011 & -0.220 & 0.021 & -0.272 \\
\hline $\begin{array}{l}\text { Ketidakserasian keluarga } \\
\text { (X12) }\end{array}$ & -0.169 & -0.050 & 0.328 & 0.009 \\
\hline Kemampuan keluarga (X13) & -0.256 & 0.202 & -0.072 & 0.295 \\
\hline Penuh perhatian (X14) & $-0.402 *$ & $0.482 * *$ & $0.460 *$ & 0.325 \\
\hline Penuh motivasi (X15) & $-0.361 *$ & $0.368^{*}$ & $0.611 * *$ & 0.272 \\
\hline Memberi contoh (X 16) & -0.310 & $0.611 * *$ & 0.318 & $0.500 *$ \\
\hline Dinamis (X17) & $-0.439 *$ & $0.413^{*}$ & 0.283 & 0.339 \\
\hline Tangguh (X18) & -0.227 & $0.414 *$ & $0.458^{*}$ & $0.435^{*}$ \\
\hline Berani berkorban (X 19) & $-0.383 *$ & $0.583^{* *}$ & $0.411 *$ & $0.501 * *$ \\
\hline Hubungan informal (x200 & $-0.511 * *$ & $0.579 * *$ & $0.372 *$ & $0.559 * *$ \\
\hline Mampuberkomunikasi(X21) & $-0.491 * *$ & 0.333 & $0.494 * *$ & $0.539 * *$ \\
\hline
\end{tabular}

Keterangan $* *$ : Berpengaruh pada taraf kepercayaan $99 \%$

* : Berpengaruh pada taraf kepercayaan $95 \%$ 
pelaksanaan pembinaan itu sendiri dan terutama dari cara pandang anak jalanan. Sesuai dengan pendapat Nord (Gibson dan Donnely, 1994) yang menyatakan bahwa cara seseorang melihat situasi seringkali mempunyai arti yang lebih penting untuk memahami perilaku seseorang dari pada situasi itu sendiri. Hal tersebut sesuai dengan pendapat Rakhmat (1998) bahwa yang menentukan persepsi bukan jenis atau bentuk stimuli, tetapi karakteristik orang yang memberi respon terhadap stimuli itu dan sangat dimungkinkan orang yang berbeda yang dapat dana, dibandingkan dengan di rumah singgah yang tidak dapat dana terlihat pada Tabel 5. Terutama untuk faktor yang berkaitan dengan tipe kepribadian pembina rumah singgah. Hal ini memperlihatkan bahwa tipe kepribadian pembina rumah singgah memiliki kontribusi yang cukup besar di rumah singgah yang tidak dapat dana. Fenomena tersebut memperlihatkan bahwa ada faktorfaktor yang berhubungan pada saat seseorang mempersepsi sesuatu. Hal ini sesuai dengan pendapat Rakhmat (1998) behwa persepsi ditentukan oleh faktor

Tabel 6. Bentuk Pembinaan yang Paling Penting dan

Paling Dipahami/Disukai oleh Anak Jalanan

\begin{tabular}{|l|c|c|c|c|c|c|c|c|}
\hline & \multicolumn{4}{|c|}{ Pembinaan yang Penting } & \multicolumn{3}{c|}{ Pembinaan yang Dipahami/Disukai } \\
\hline $\begin{array}{l}\text { Bentuk } \\
\text { Pembinaan }\end{array}$ & $\begin{array}{l}\text { Rumah Singgah } \\
\text { dapat dana }\end{array}$ & \multicolumn{2}{|c|}{$\begin{array}{c}\text { Rumah Singgah } \\
\text { tidak dapat dana }\end{array}$} & \multicolumn{2}{c|}{$\begin{array}{c}\text { Rumah Singgah } \\
\text { dapat dana }\end{array}$} & \multicolumn{2}{c|}{$\begin{array}{c}\text { Rumah Singga } \\
\text { tidak dapat dana }\end{array}$} \\
\hline & Observed & Residual & Observed & Residual & Observed & Residual & Observed & Residua \\
\hline Tidak tahu & 8 & 0.5 & 16 & 8.5 & 10 & 4.0 & 16 & 6.0 \\
\hline $\begin{array}{l}\text { Pembinaan } \\
\text { Fisik }\end{array}$ & 0 & -7.5 & 0 & -7.5 & 2 & -4.0 & 0 & -10.0 \\
\hline $\begin{array}{l}\text { Pembinaan } \\
\text { Mental }\end{array}$ & 8 & 0.5 & 8 & 0.5 & 6 & 0.0 & 4 & -6.0 \\
\hline $\begin{array}{l}\text { Pembinaan } \\
\text { Sosial }\end{array}$ & 6 & -1.5 & 4 & -3.5 & 3 & -30 & 0 & -10.0 \\
\hline $\begin{array}{l}\text { Pembinaan } \\
\text { Ketrampilan }\end{array}$ & 8 & 0.5 & 2 & -5.5 & 9 & 3.0 & 10 & 0.0 \\
\hline Jumlah & 30 & & 30 & & 30 & & 30 & 0.0 \\
\hline
\end{tabular}

mempersepsi sesuatu dengan cara yang berbeda. Hal tersebut sesuai pula dengan pendapat Nord (Gibson dan Donnely, 1994) bahwa individu yang berbeda akan "melihat" barang yang sama dengan cara yang berbeda-beda.

Faktor-faktor yang berhubungan dengan persepsi anak jalanan terhadap pembinaan di rumah singgah yang dapat dana terlihat pada Tabel 4 dan di rumah singgah yang tidak dapat dana terlihat pada Tabel 5.

Tabel 4 menunjukan bahwa hanya sedikit fakor yang berhubungan dengan persepsi anak jalanan di rumah singgah personal dan faktor situasional.

Bentuk pembinaan yang paling penting dan paling dipahami/disukai oleh anak jalanan di rumah singgah yang dapat dana dengan yang tidak dapat dana terlihat pada Tabel 6 dan Tabel 7.

Hasil uji Chi-Square pada Tabel 6 dan 7 menunjukan hubungan nyata dalam menilai pembinaan yang dirasakan paling penting dan paling dipahami/disukai. Di rumah singgah yang mendapat dana frekuensi responden yang menilai pembinaan paling penting yaitu pembinaan mental dan pembinaan ketrampilan menunjukkan hasil yang seimbang, dengan 
masing-masing perolehan cenderung menyebar merata. Hasil pengujian ChiSquare 0.400 yang lebih kecil dibandingkan dengan hasil Chi Tabel yaitu 7.814 dengan nilai frekuensi yang diharapkan untuk masing-masing sel adalah 7.5 yang berarti bahwa bentukbentuk pembinaan yang ada di rumah singgah cenderung dirasakan penting secara merata oleh anak jalanan.

Di rumah singgah yang tidak mendapat dana frekuensi responden yang menilai pembinaan yang paling penting yaitu pembinaan mental penyebarannya cenderung tidak merata, terlihat dari frekuensi yang bervariasi dengan jumlah yang tidak tahu pembinaan yang paling penting lebih dari $50 \%$. Dengan hasil pengujian Chi-Square 15.333 yang lebih besar dari Chi-Tabel 7.814 dengan frekuensi yang diharapkan untuk masingmasing sel adalah 7.5. Hal ini diduga disebabkan dalam pembinaan mental anak dikenalkan dengan nilai-nilai keagamaan, nilai-nilai budi pekerti dan nilai-nilai kesetiakawanan. Walau dalam penerapannya masih kurang tetapi mereka menyadari bahwa hal ini adalah penting.

Pembinaan
dipahami/disukai yaitu $\begin{array}{r}\text { paling } \\ \text { pembinaan }\end{array}$ ketrampilan : di rumah singgah yang mendapat dana, cenderung menyebar merata dirasakan oleh anak jalanan dengan hasil Chi-Square 8.333 yang lebih kecil dari Chi-Tabel 9.4877 dengan frekuensi sel yang diharapkan 6.0. Sedangkan bagi rumah singgah yang tidak mendapat dana, pembinaan yang dirasakan paling dipahami/disukai sama, pembionaan ketraampilan. Menunjukan hasil cenderung menyebar tidak merata dengan hasil uji Chi-Square yang diperoleh 7.200 yang lebih besar dari chi table 5.9915.

Secara umum dari kondisi di atas terlihat bahwa pembinaan ketrampilan bagi kedua jenis rumah singgah adalah merupakan pembinaan yang paling dipahami/disukai oleh anak jalanan. Hal ini diduga disebabkan dalam pembinaan ketrampilan anak dapat melihat dan mempraktekan secara langsung pembinaan yang diperoleh (learning by doing) sehingga proses pemahaman anak akan lebih cepat dicapai.

Hal di atas sesuai dengan pendapat Garnadi (1971) tentang penyuluhan bahwa basil penangkapan dari mendengarkan saja adalah $10 \%$, hasil penangkapan dari melihat saja adalah 50\%, hasil penangkapan dari mendengar, melihat dan mengerjakan sendiri (praktek) adalah 90\%. Karenanya dalam upaya menyampaikan pembinaan/ penyuluhan kepada anak jalanan diharapkan dapat digunakan metode yang bervariasi dengan penekanan pada praktek langsung atau setidaknya dengan cara role play atau dengan simulasi. Tujuannya agar anak lebih banyak melakukan retensi dari materi yang diberikan.

Frekuensi responden yang tidak tahu pembinaan yang paling dipahami/disukai dan yang paling penting di kedua rumah singgah menunjukan basil yang tidak kecil. Hal ini diduga disebabkan oleh kurangnya sosialisasi oleh pembina dengan cara yang persuasif kepada anak jalanan tentang bentuk pembinaan yang ada di rumah singgah.

Dalam hal ini pemahaman anak jalanan terhadap sesuatu adalah juga merupakan kebutuhan pokok. Sesuai pendapat Maslow (1984) bahwa keinginan untuk mengetahui dan memahami itu sendiri adalah juga merupakan kebutuhan pribadi seperti kebutuhhan pokok, yang juga menuntut untuk dipenuhi, sama seperti kebutuhan pangan atau sandang.

Demikian pula untuk anak jalanan dalam mengikuti bimbingan sosial di rumah singgah. Bila anak merasa ada kegiatan yang lebih dipahami/disukai 
dan lebih penting bagi dirinya, maka akan mendorong anak untuk tetap berada di rumah singgah dan mengikuti pembinaan karena ingin lebih memahami kegiatan tersebut. Sebaliknya, bila anak merasa bahwa pembinaan di rumah singgah ternyata tidak memenuhi kebutuhan pokoknya untuk mengetahui dan lebih memahami suatu kegiatan pembinaan yang ada di rumah singgah, maka anak jalananpun akan acuh tak acuh dengan pembinaan yang ada. Akibat lebih lanjut anak menjadi tidak tahu pembinaan mana yang lebih dipahami/disukai dan lebih penting bagi dirinya dari keseluruhan kegiatan pembinan yang ada. Dalam hal ini asumsi Maslow berlaku.

\section{Rujukan}

Fukuyama, F. 1999. The Great Disruption Human Nature and The Reconstitution of Social Order. A Touchstone Book, Published by Simon and Schuster, New York, London, Toronto, Synedy, Singapore.

Gilbert, Neil \& Specht, Hary. 1986. Dimension of Social Welfare Policy. Prentice Hall Englewood Cliffs. New Jersey.

Goode, William J. 1993. Sosiologi Keluarga. Bina Aksara. Jakarta.

Garnadi, Attila. 1971. Penggunaan Visual Aid dalam Penyuluhan Pertanian. Direktorat Penyuluhan Pertanian. Jakarta.

Gibson, Ivancevich dan Donnely. 1994. Organisaasi dan Manajemen. Erlangga. Jakarta.

Irwanto. 1996. Pekerja Anak di Tiga Kota Metropilitan : Jakarta, Surabaya dan Medan. Pusat Penelitian Atmajaya. Jakarta.

Mohammad Farid dan Jeffry Anwar. 1998. Ringkasan Analisa Situasi Anak yang Membutuhkan Perlindungan Khusus. PKPM Atmajaya. Departemen Sosial. UNICEF. Jakarta.

Kerlinger, F. N,. 1971. Foundation of Behavioral Research, 2th Ed,. New York. MacMillan. 
Maslow, Abraham H. 1984. Motivasi dan Kepribadian. PT Pustaka Binaman Presindo. Gramedia. Jakarta.

Nazir. 1983. Metode Penelitian. Ghalia Indonesia. Jakarta.

Nawawi, Hadari. 1998. Metode Penelitiaan Bidang Sosial. Gadjah Mada University Press. Yoyakaarta

Popenoe, D. 1989. Sociology. 7th ed. Prentice hall, Englewood Cliffs. New Jersey 07632.

Rakhmat, Jalaludin. 1998. Psikologi Komunikasi. PT Remaja Rosdakarya. Bandung.

Singarimbun, Masri. dan Sofian Effendi. 1987. Metode Penelitian Survai. LP3ES. Jakarta. 